Ayurlog: National Journal of Research in Ayurved Science

\title{
Critical Comparative Study of Month wise Intrauterine Foetal Development As Per Ayurvedic And Jyotish Science W.S.R.To Modern Embryogenesis
}

\author{
Subhash D. Waghe*1, Shrikant Darokar ${ }^{2}$, Y.V. Rajyalakshmi Rao ${ }^{3}$
}

1. HOD - Dept. of Roga Nidana \& Vikruti Vigyana, KDMG Ayurvedic College, Chalisgaon, Maharashtra.

2. HOD- Dept. of Sharir Rachana, SRC Ayurved College, Chikhli, Maharashtra - 443 201

E-mail- shrikantdarokar@gmail.com

3. Ph.D (Scholar - Vedang Jyotish), Kavi Kulguru Kalidas Sanskrit, Vishwavidyalaya, Ramtek, Maharashtra E-mail - yvrajyalakshmi@gmail.com

*Corresponding author: E-mail - carenidan@ rediffmail.com (contact no. 7038000648)

\begin{abstract}
The Jyotish science is complimentary the Ayurvedic medical science. The principles of Jyotish science have been in applied in Ayurvedic science at various places. The month wise description of intrauterine embryonic and foetal development is mentioned in both ancient Ayurvedic and Jyotish science. Modern medical science had made enormous progress in understanding the process of embryogenesis and organogenesis in intrauterine life with modern technical advances. The $5^{\text {th }}$ and $6^{\text {th }}$ month description of foetal development is more precise in Jyotish science than Ayurvedic science. The $1^{\text {st }}$ to $2^{\text {nd }}$ month description of embryonic development is more precise in modern medical science. Hence, there is a need to study the

month wise intrauterine foetal development as per Ayurvedic and Jyotish
\end{abstract} FUR Science in the light of modern medical mbryogenesis. The critical comparison of Ayurvedic and Jyotish science, shows marked similarities between the description of monthly embryonic and foetal development. The extra description mentioned in Jyotish science related monthly foetal development should be incorporated in Ayurvedic science. The description of monthly embryonic and foetal development in Ayurvedic and Jyotish science, can fairly be correlated with modern description of embryogenesis and foetal organogenesis and proper blending of ancient knowledge with modern knowledge could be done.

KEYWORDS - Embryogenesis, Foetal development

\section{INTRODUCTION}

The Jyotish science is complimentary to the Ayurvedic medical science. The 
principles of Jyotish science have been in applied in Ayurvedic science at various places with reference to collection and storage of drugs, administration of therapy, surgical intervention and prognostic evaluation. The month wise description of intrauterine embryonic and foetal development is mentioned in both ancient Ayurvedic and Jyotish science. Modern medical science had made enormous progress in understanding the process of embryogenesis and organogenesis in intrauterine life with modern technical advances. The basic concept of fusion of male and female gametocyte to form zygote and zygotic division leading to formation of embryo is common in all the three sciences. However, the $5^{\text {th }}$ and $6^{\text {th }}$ month description of foetal development is more precise in Jyotish science than Ayurvedic science. The $1^{\text {st }}$ to $2^{\text {nd }}$ month description of embryonic development more precise in modern medical science Hence, there is a need to study the month wise intrauterine foetal development as per Ayurvedic and Jyotish Science in the light of modern medical embryogenesis. Acharya Sushruta, had given the guideline in sutrasthana of his treatise to nurture and advance the science and study it from all angles. In accordance to the guidelines given by acharya, the additional description of foetal development from Jyotish science and modern medical science can be incorporated in Ayurvedic science.

\section{MATERIAL \& METHOD}

Literary method of research was adopted in the present study. Critical and comparative study of Ayurvedic literature, jyotish science literature and modern medical science literature was done to come to logical conclusion.

\section{REVIEW OF AYURVEDIC \\ LITERATURE}

Cell Division As The Cause of Embryonic Development

- प्राणः तु बीजधातुं हि विभजति.....गर्भस्य सर्व अंग अवयवः। (का.सं.शा. -असमानगोत्रीय अध्याय)

- यथार्थं उष्मणा युक्तो वायु: सत्रोतांसि प्रजायते । अनुप्रविश्य पिशितं पेशी: विभजते तथा ।। .....सिराम् आप्नुयात् ... .....करोति आशय संभवम् ।। (सु.शा. $4 / 28-30)$

- सर्व एव अवयवा: परमाणु भेदेन अति सौक्ष्म्यात् असंख्येयतां यान्ति ।। तेषां संयोग विभागे परमाणूनां कर्मप्रेरितो वायु: कारणम् ।। (अ.सं.शा. 5/95-96)

- कर्म च उदित वायु वशात् संयुक्या: परमाणवः कार्यद्रव्यम् आरभते द्वि अणुक आदि कमेण। (इंदु-अ.सं.शा. $5 / 96)$

- ते च परमाणवः प्रतिक्षणं सजातीय विजातीय संयोग विभागाभ्यां शरीरभावेन वर्तते । यो वा बाल आसीत् स एव युवत्वं प्रतिपन्न इति एकस्य नानात्व योगात् ।। इंदु-अ.सं.शा. 5/95

(प्राण: =vital force, बीजधातुं हि विभजति =divides the zygot, उष्मणा युक्तो वायु: = Vata accompanied with the heat, अनुप्रविश्य पिशित = enters the muscular mass पेशी: विभजते $=$ divides the cells, स्त्रोतांसि दारयेत $=$ creates the systems by tearing करोति आशय $=$ give rise to different organs, परमाणु $=$ cell, एकस्य नानात्व योगात् = divide into number of cells, द्वि अणुक आदि कमेण =mitotic cell division 


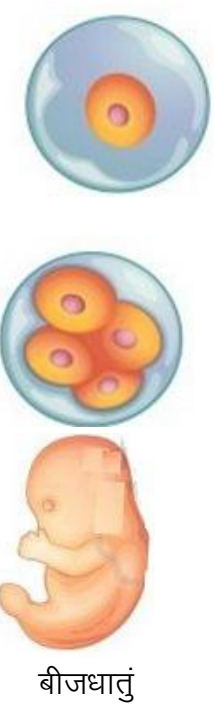

हि विभजति
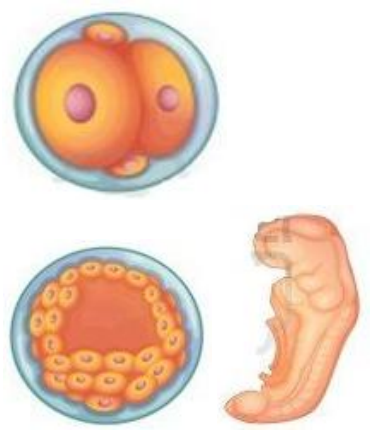

द्वि अणुक आदि कमेण बीजधातुं एकस्य नानात्व योगात् करोति आशय

(Zygote)

(Mitosis)

(Cell Differentiation \& Organogenesis )

As per Acharya Kashyapa, the vital force divides the zygot during embryogenesis. [K.S.]

As per Acharya Sushruta, the Vata accompanied with the heat enters the muscular mass and divides the cells creates the systems by tearing apart the muscles, also give rise to different organs, blood vessels and hollow organs like heart by dialting property (vyas guna). [S.Sha. 4/28-30]

As per Acharya Vagbhata and Indukara, The smallest part of the body organ is 'Parmanu' (cell) . Its division and union is done by the Vata aimed for that specialized work. The one parmanu (cell) divide into number of cells by mitotic cell division (Ekasya Nanatwa yogat Dwi Anuk adi kramena)from infancy to youthness. [A.S.Sha. 5/95-96 \& Indu- Shashilekha]

\section{OBSERVATIONS}

1] First Month : Ayurveda Shastra :

- तत्र प्रथमे मासि कललं जायते । सु. शा. $3 / 18$

- अव्यक्तः प्रथमे मासि सप्ताहात् कलली भवेत्। पुसंवनान् पूर्व व्यक्तेःप्रयोजयेत् । अ.हृ.शा. $1 / 37$

- सप्ताहात् आद्य: गर्भगोलक: श्लेष्मपिण्डिभूतो भवेत्। सप्ताहानन्तरं व्यक्ताकृति कलली भवेत्। अरूणदत्त

As per Ayurvedic science, in the first month of pregnancy, the intrauterine embryo is in the form of 'Kalala' i.e. like bubble. [S.Sha. 3/18]. As per acharya Vagbhata, initially it is formless. After a week's time it becomes bubble like. [A.H. Sha. 1/37]. Acharya Arundutta, is of the view that initially embryo is like thick round sputum. After a week, it becomes bubble like i.e increases in size. This appears to be very scientific as initial zygotic division is without the increase in size and after a week it increases in size to o into various stages of embryonic development.

Jyotish Shastra :

- कललं घनं अंकुरं अस्थि चर्म अगज चेतनताः । सित कुज जीव सूर्य चंद्र अर्कि बुधा: परतः ।। उदयचंद्र सूर्यनाथा क्रमशः गदिता । भवन्ति शुभाशुभं च मासाधिपतेः सदृशं। बृहत्जातकं $4 / 16$

- कलल घन अवयव अस्थि त्वक् रोम स्मृद् भवाः क्रमशः । मासेषु शुक कुज जीव सूर्य चन्द्र अर्कि सौम्यानाम् ।। अशनोद्वेगप्रसवा: परतो लग्नेश चनद्रसूर्याणाम् | लघुजातकं $5 / 7$

भटोत्पल टिका - आद्यो तु मासे कललं ।

भटोत्पल टिका - गर्भस्य प्रथमे मासि कललं भवति। शुक्रशोणित घने संमिश्रोभूते तत्र गर्भस्य तस्मिन माासे सितः शुको अधिपतिः।

As per jyotish science also, in the first month of pregnancy, the intrauterine embryo is in the form of 'Kalala' i.e. like 
bubble. This phase is ruled by the planet Venus (Shukra) [B.Ja. 4/16].

As per the modern science, in first month embryonic developments takes place as follows :

During $1^{\text {st }}$ week, Zygote undergoes cell division producing cluster of cells of same size but no significant growth. This stage is called as cleavage which converts into morula and blastocyte stage. The 4 cell divisions leads to dense ball of 16 cells which is termed as morula. The 7 clevage / cell division leads to the formation of dense ball of 128 cells which is termed as blastula. After this, rotational arrangement of blastomeres leads to the formation of blastocyte .

During $2^{\text {nd }}$ week, blastocyte undergoes trophoblaste stage with implantation in uterine wall and with outer cell layer (tropoectoderm) and inner cell mas (endoblast). Fluid collects between oute and inner mass and the morulla is converted into vesicle called as the blastodermic vesicle. Thus embryo becomes bilaminar. The cells of trophoblast do not contribute in the formation of embryo proper but they contribute in formation of ectoderm of chorion and placenta.

During $3^{\text {rd }}$ week, blastoderm becomes trilaminar with 3 layers. This stage characterizes with notochord, gastrulation, somitogenesis and neurogenesis. Somitogenesis begins with the formation of somitomeres (whorls of the concentric mesoderm) from which future somites (primitive segments) are produced. These tissue blocks, differentiates into skeletal muscle, vertebrae and dermis of all vertebrae. During gastrulation, cells migrate to the interior of the blastula producing 3 distinct germ layers as outer ectoderm, middle mesoderm and inner endoderm. Each of the layer give rise to certain tissues of the body. Neural fold, head fold and cardiac primordium also starts growing.

During $4^{\text {th }}$ week, heart, pharyngeal arches starts developing

\section{2] Second Month :}

Ayurveda Shastra :

- द्वितीये शीतोष्मानिलै: अभिप्रपच्यमानानां महाभूतानां संघातो घन: संजायते । सु. शा. $3 / 18$

- द्वितीये मासि कललात् घनः पेशी अथवा अर्बुदं पुंस्त्रीक्लीबा: कमात् तेभ्यः । अ.हृ. शा. $1 / 49$

- गर्भस्य हृदयं मातुः च हृदयेन तत् समबध्दं तेन गर्भिण्या नेष्टं श्रध्दाविमाननम्। अ.ह.शा. 1/52

As per Ayurvedic science, in the second month, as the Vata brings the absorption of Kapha and Pitta, the embryo becomes Ghana' i.e. solid. Acharyas are further of the view that if this solid structure is oval then offspring will be male and if this solid structure is elongated like muscle then offspring will be female and if this solid structure is like tumour then offspring will be eunach. [S.Sha. 3/18]. Acharya Vagbhata is of the view that in this month mother's heart gets connected with foetal heart through placenta and mother develops desire for eating various things. This state is called as 'Dwi Hrut' awastha in ayurveda.

\section{Jyotish Shastra :}

- कललं घनं अंकुरं अस्थि चर्म अगज चेतनताः । सित कुज जीव सूर्य चंद्र अर्कि बुधा: परतः ।।

उदयचंद्र सूर्यनाथा कमशः गदिता ।

भवन्ति शुभाशुभं च मासाधिपतेः सदृशं। बृहत्जातकं $4 / 16$ 
- कलल घन अवयव अस्थि त्वक रोम र्मृद् भवाः कमशः । मासेषु शुक्र कुज जीव सूर्य चन्द्र अर्कि सौम्यानाम् ।। अशनोद्वेगप्रसवा: परतो लग्नेश चनद्रसूर्याणाम् | लघुजातकं 5/7

भटोत्पल टिका - द्वितीये पेशिः ।

भटोत्पल टिका - द्वितीये घनता काठिण्यं भवति तत्र कुजो अंगारको अधिपतिः।

As per jyotish science also, in the second month of pregnancy the embryo becomes 'Ghana' i.e. solid. This phase is ruled by the planet Mars (Mangal). [B.Ja. 4/16].

As per the modern science, in second month embryonic developments takes place as follows :

During $5^{\text {th }}$ week, rudiments of liver, gut starts developing, leg buds, nasal plate and hand plate start growing.

During $6^{\text {th }}$ week early face starts developing. Auricular and foot plate start growing. Finger start raying.

During $7^{\text {th }}$ week, head and limb starts developing. Ossification commences, Straightening of trunk occur.

$8^{\text {th }}$ week marks the last stage of embryonic development. Upper limbs become longer and bent at elbow. Hands and feet turn inward. Eyelids and external ear starts appearing. Head becomes round. After this stage embryo is called as foetus.

\section{3] Third Month :}

\section{Ayurveda Shastra :}

- तृतीये हस्तपादशिरसां पंच पिण्डका निवर्तन्ते अंगप्रत्यंगविभागः च सूक्ष्मो भवति । सु. शा. $3 / 18$

- व्यक्ति भवति मासे अस्य तृतीये गात्रपंचकम् |मूर्द्धा द्वे सक्थिनी बाहू सर्व सूक्ष्म अंगजन्म च। अ.हृ.शा. 1/54-55

As per Ayurvedic science, in the third month, hands, legs and head becomes prominent and all rudimentary minute organ becomes expressed. [S.Sha. 3/18]

As per modern science, also upto 2 months there is embryonic stage. After which foetal stage starts from the $3^{\text {rd }}$ month. At the completion of embryogenesis, all body parts are fully expressed.

\section{Jyotish Shastra :}

- कललं घनं अंकुरं अस्थि चर्म अगज चेतनताः । सित कुज जीव सूर्य चंद्र अर्कि बुधा: परतः ।। उदयचंद्र सूर्यनाथा कमशः गदिता । भवन्ति शुभाशुभं च मासाधिपतेः सदृशं। बृहत्जातकं $4 / 16$

- कलल घन अवयव अस्थि त्वक् रोम स्मृद् भवाः क्रमशः । मासेषु शुक कुज जीव सूर्य चन्द्र अर्कि सौम्यानाम् ।। अशनोद्वेगप्रसवा: परतो लग्नेश चनद्रसूर्याणाम् | लघुजातकं $5 / 7$

भटोत्पल टिका - तृतीये अपि भवन्ति शाखा: । भटोत्पल टिका - तृतीये अंकुरोत्पत्तिः स्ताद्यवयव जन्म तत्र जीवो बृहस्पतिः अधिपतिः।

As per jyotish science, in the third month of pregnancy the embryo becomes like Ankura i.e. organs starts sprouting. This phase is ruled by the planet Jupiter (Guru). [B.Ja. 4/16].

As per modern science, from $3^{\text {rd }}$ month onwards, embryo is called as foetus with all body parts which start growing simultaneously.

\section{4] Fourth Month :}

\section{Ayurveda Shastra :}

- चतुर्थे सर्व अंगप्रत्यंगविभागः प्रव्यक्तो भवति, गर्भह्ददय प्रव्यक्तिभावात् चेतनाधातुः अभिव्यक्तो भवति । तर्मात् नारी द्वौ हृदिनीं आचक्षते। सु. शा. $3 / 18$

- चतुर्थे व्यक्तता अंगानाम् । अ.ह.शा. $1 / 57$ 
As per Ayurvedic science, in the fourth month, body parts become more prominent. Foetal heart sounds become evident as the Chetana dhatu (vital living force) becomes active and the seat of Chetana is heart. At this stage mother develops desire for various things which should be fulfilled. If these desires are not fulfilled then congenital anamolies results in the form of lame, dwarf, blind, hunched and mentally retarded child. [S.Sha. 3/18]. As per acharya Vagbhata, foetal parts are felt at this stage as they are expressed.

\section{Jyotish Shastra :}

- कललं घनं अंकुरं अस्थि चर्म अगज चेतनताः । सित कुज जीव सूर्य चंद्र अर्कि बुधा: परतः ।।

उदयचंद्र सूर्यनाथा कमशः गदिता । भवन्ति शुभाशुभं च मासाधिपतेः सदृशं।। बृहत्जातकं $4 / 16$

- कलल घन अवयव अस्थि त्वक् रोम जण खि स्मृद् भवाः कमशः । मासेषु शुक् कु जीव सूर्य चन्द्र अर्कि सौम्यानाम् अशनोद्वेगप्रसवा: परतो लग्नेश चनद्रसूर्याणाम् | लघुजातकं $5 / 7$

भटोत्पल टिका - अस्थीन्यथ स्नायुशिराः चतुर्थे ।

भटोत्पल टिका - चतुर्थे अस्थिसंभवः तत्र सूर्यो अधिपतिः ।

As per jyotish science, in the fourth month of pregnancy the bone starts becoming prominent. This phase is ruled by the planet Sun (Surya). [B.Ja. 4/16]

\section{5] Fifth Month :}

\section{Ayurveda Shastra :}

- पंचमे मनः प्रतिबुध्दतरं भवति । सु. शा. $3 / 30$

- चेतनाया: च पंचमे । अ.ह.शा. 1/57

As per Ayurvedic science, in the fifth month, the mind and heart becomes active. [S.Sha. 3/30 and A.H. Sha. 1/57]

Jyotish Shastra :
- कललं घनं अंकुरं अस्थि चर्म अगज चेतनताः । सित कुज जीव सूर्य चंद्र अर्कि बुधा: परतः ।।

उदयचंद्र सूर्यनाथा कमशः गदिता । भवन्ति शुभाशुभं च मासाधिपतेः सदृशं। बृहत्जातकं $4 / 16$

- कलल घन अवयव अस्थि त्वक् रोम स्मृद् भवाः कमशः । मासेषु शुक्र कुज जीव सूर्य चन्द्र अर्कि सौम्यानाम् ।। अशनोद्वेगप्रसवा: परतो लग्नेश चनद्रसूर्याणाम् । लघुजातकं $5 / 7$

भटोत्पल टिका - मज्जान्त्रचर्माणि अपि पंचमे तु ।

भटोत्पल टिका - पंचमे चर्मसंभव: चन्द्र अधिपतिः।

As per jyotish science, in the fifth month of pregnancy the skin starts becomes prominent. This phase is ruled by the planet Moon (Chandra). [B.Ja. 4/16]

As per acharya Bhatotpala, in the fifth honth, the bone marrow, nervous mass majja), intestine (antra), skin (charma) grows.

\section{6] Sixth Month :}

\section{Ayurveda Shastra :}

- षष्ठे बुद्धिः । सु. शा. $3 / 30$

- षष्ठे स्नायुसिरारोमबलवर्णनखत्वचाम् । अ.ह.शा. $1 / 57$

As per Ayurvedic science, in the sixth month, brain becomes active. [S.Sha. 3/30] As per acharya Vagbhata, in the sixth month the ligaments, blood vessels, hairs, nails and skin is expressed.

\section{Jyotish Shastra :}

- कललं घनं अंकुरं अस्थि चर्म अगज चेतनताः । सित कुज जीव सूर्य चंद्र अर्कि बुधा: परतः ।।

उदयचंद्र सूर्यनाथा क्रमशः गदिता ।

भवन्ति शुभाशुभं च मासाधिपतेः सदृशं।।

बृहत्जातकं $4 / 16$ 
- कलल घन अवयव अस्थि त्वक रोम र्मृद् भवाः कमशः । मासेषु शुक्र कुज जीव सूर्य चन्द्र अर्कि सौम्यानाम् ।। अशनोद्वेगप्रसवा: परतो लग्नेश चनद्रसूर्याणाम् | लघुजातकं 5/7

भटोत्पल टिका - षष्ठे तु असृक् रोम नखै: यकृत च ।

भटोत्पल टिका - षष्ठे अंगसम्भवो लोमजन्म तत्र अर्कि सौरो अधिपतिः।

As per jyotish science, in the sixth month of pregnancy, various body parts starts becoming prominent. This phase is ruled by the planet Saturn (Shani). [B.Ja. 4/16]

As per acharya Bhatotpala, in this month, hairs, nails and liver grows.

\section{7] Seventh Month :}

\section{Ayurveda Shastra :}

- सप्तमे सर्व अंगप्रत्यंगविभागः प्रव्यक्ततरः

। सु. शा. $3 / 30$

- सर्वेः सर्वांग सम्पूर्णो भावैः पुष्यति सप्तमे | अ.हृ.शा. 1/58

As per Ayurvedic science, in the seventh month, the differentiation of all the body parts takes place and are fully formed in its entirety . [S.Sha. 3/30 \& A.H.Sha. 1/58]

\section{Jyotish Shastra :}

- कललं घनं अंकुरं अस्थि चर्म अगज चेतनताः । सित कुज जीव सूर्य चंद्र अर्कि बुधाः परतः । ।

उदयचंद्र सूर्यनाथा क्रमशः गदिता ।

भवन्ति शुभाशुभं च मासाधिपतेः सदृशं।। बृहत्जातकं $4 / 16$

- कलल घन अवयव अस्थि त्वक् रोम स्मृद् भवाः क्रमशः । मासेषु शुक्र कुज जीव सूर्य चन्द्र अर्कि सौम्यानाम् ।। अशनोद्वेगप्रसवा: परतो लग्नेश चनद्रसूर्याणाम् | लघुजातकं $5 / 7$

भटोत्पल टिका - चेतस्विता सप्तम मासि चिंत्या

भटोत्पल टिका - सप्तमे चेतनता सम्भवति चेतनता स्वभावः तत्र बुधो अधिपतिः।
बुधमासात्परतो अन्ये शेषा मासास्ते गर्भस्य आशन उद्वेगप्रसवकराः ते च उदयपति चन्द्रसूर्यनाथाः स्वामिनः कमशो गर्दिता उक्ताः।

As per jyotish science, in the seventh month of pregnancy, foetus starts moving (chetanta). This phase is ruled by the planet Mercury (Budha). [B.Ja. 4/16]

\section{8] Eighth Month :}

\section{Ayurveda Shastra :}

- अष्टमे अस्थिर भवति ओजः। सु. शा. $3 / 30$

As per Ayurvedic science, in the eighth month, the Oja is unstable, hence if the baby is delivered in this month, does not survive. After the eighth month the baby may get delivered in $9^{\text {th }}, 10^{\text {th }}, 11^{\text {th }}$ or $12^{\text {th }}$ month. [S.Sha. 3/30]

\section{Jyotish Shastra :}

- कललं घनं अंकुरं अस्थि चर्म अगज चेतनताः । सित कुज जीव सूर्य चंद्र अर्कि बुधाः परतः ।।

उदयचंद्र सूर्यनाथा कमशः गदिता । भवन्ति शुभाशुभं च मासाधिपतेः सदृशं।। बृहत्जातकं $4 / 16$

- कलल घन अवयव अस्थि त्वक् रोम स्मृद् भवाः क्रमशः । मासेषु शुक् कुज जीव सूर्य चन्द्र अर्कि सौम्यानाम् ।। अशनोद्वेगप्रसवा: परतो लग्नेश चनद्रसूर्याणाम् । लघुजातकं $5 / 7$

भटोत्पल टिका - तृष्णाशनास्वादनम् अष्टमे स्यात् ।

भटोत्पल टिका - तत्र अष्टमे मासि गर्भस्थो जन्तुः अशनं करोति। मात्रा भुक्तं पीतं रसादि तस्य नाभिलग्ननालेन संकमते। तत्र गर्भाधानलग्नाधिपतियो: ग्रहः स मासाधिपतिः।

As per jyotish science, in the eighth month of pregnancy, foetus senses the taste from the maternal nutrition. This phase is ruled by the planet of Aadhan Lagna. [B.Ja. 4/16]

9] Ninth Month :

Ayurveda Shastra : 
- नवम् दशमे एकादश द्वादशानाम् अन्यतमस्मिन् जायते अतो अन्यथा विकारी भवति । सु. शा. $3 / 30$

As per Ayurvedic science, foetus gets delivered in $9^{\text {th }}, 10^{\text {th }}, 11^{\text {th }}$ or $12^{\text {th }}$ month. After that is abnormal.

\section{Jyotish Shastra:}

- कललं घनं अंकुरं अस्थि चर्म अगज चेतनताः । सित कुज जीव सूर्य चंद्र अर्कि बुधा: परतः ।।

उदयचंद्र सूर्यनाथा कमशः गदिता ।

भवन्ति शुभाशुभं च मासाधिपतेः सदृशं।।

\section{बृहत्जातकं $4 / 16$}

- कलल घन अवयव अस्थि त्वक् रोम स्मृद् भवाः कमशः । मासेषु शुक् कुज जीव सूर्य चन्द्र अर्कि सौम्यानाम् ।। अशनोद्वेगप्रसवा: परतो लग्नेश

\section{चनद्रसूर्याणाम् | लघुजातकं $5 / 7$}

भटोत्पल टिका - स्पर्शोपरोधो नवमे रतिः च। स्रोतोभि: उद्घाटितपूर्णदेहो गर्भो ।

भटोत्पल टिका - नवमे गभेस्य उद्वेगो भवर्व तत्र चन्द्र अधिपतिः।

As per jyotish science, in the ninth month of pregnancy, foetus becomes restless and moves frequently. This phase is ruled by the planet Moon (Chandra). [B.Ja. 4/16]

As per Bhatotpala all the systems and body parts are completely formed in this month.

\section{0] Tenth Month :}

\section{Ayurveda Shastra :}

- नवम् दशमे एकादश द्वादशानाम् अन्यतमस्मिन् जायते अतो अन्यथा विकारी भवति । सु. शा. $3 / 30$

\section{Jyotish Shastra :}

- कलल घन अवयव अस्थि त्वक् रोम स्मृद् भवाः कमशः । मासेषु शुक्र कुज जीव सूर्य चन्द्र अर्कि सौम्यानाम् ।। अशनोद्वेगप्रसवा: परतो लग्नेश चन्द्रसूर्याणाम् । लघुजातकं $5 / 7$

भटोत्पल टिका - दशमे गर्भस्य प्रसवः प्रसूतिः भवति तत्र सूर्यो रविः अधिपतिः।
As per jyotish science, in the tenth month of pregnancy, foetus gets delivered. This phase is ruled by the planet Sun (Suryra). [B.Ja. 4/16]

\section{DISCUSSION:}

Both science holds the same view as far as intrauterine foetal development is concerned in first and second month. About the development in third month both science are of the same opinion that rudiments of hands and feet (shakha or hastapada) starts appearing in this month. About the development in fourth, fifth and sixth month, opinions differ. As per Ayurveda, in fourth month, heart activity becomes evident whereas as per jyotish science, in this month bones becomes prominent. In fifth month, as per Ayurveda, mind becomes active whereas as per jyotish science, during $5^{\text {th }}$ month, the bone marrow, nervous mass (majja), thtestine (antra), skin (charma) grows. In the sixth month of foetal development, as per Ayurveda, brain becomes active whereas as per jyotish science, various body parts starts becoming prominent along with hairs, nails and liver. In the seventh month as per Ayurveda, differentiation of all the body parts takes place. Jyotish science also holds the same view and also mentions about the foetal movements. As per ayurveda, in eighth month, the Oja is unstable and it constantly moves from mother to foetus and vice versa. Hence, if baby is delivered in this month have less chances of survival. Whereas as per jyotish science, sensory development occurs in this month. Both science agree that in ninth month complete foetal development take place and foetus may get delivered $9^{\text {th }}$ or $10^{\text {th }}$ month. Ayurveda, considers delivery of the baby upto 12 months as normal and 
after that it is abnormal. But jyotish science, limits the delivery period upto 10 months only. Both these ancient descriptions when studied in the light of modern medical knowledge, it is found that there upto embryonic stage, the modern science studies the embryonic development on weekly basis whereas Ayurvedic and Jyotish science studies it on monthly basis. The modern concept of cell division in zygote leading to formation of embryo is also seen in Ayurvedic science.

The modern science studies the embryogenesis in terms of zygotic division, cleavage, morulla, blastocyte, trophoblast, gastrulation and formation of three germinal layers, smoitogenesis and formation of primitive segments of the body.

\section{RESULT:}

1. Modern science studies the embryonic development on weekl basis whereas Ayurvedic and Jyotish science studies it on monthly basis.

2. The $5^{\text {th }}$ and $6^{\text {th }}$ month description of foetal development is more precise in Jyotish science than Ayurvedic science.

3. The $1^{\text {st }}$ to $2^{\text {nd }}$ month description of embryonic development is more precise in modern medical science.

4. The modern concept of cell division in zygote leading to formation of embryo is also seen in Ayurvedic science.

5. The ancient description of month wise foetal development can also be blended with modern scientific and more accurate description.

\section{CONCLUSION:}

1. The monthly embryonic and foetal development is well described in the Ayurvedic as well as Jyotish science.

2. The critical comparison of Ayurvedic and Jyotish science, shows marked similarities between the description of monthly embryonic and foetal development.

3. The description of monthly embryonic and foetal development in Ayurvedic and Jyotish science, can fairly be correlated with modern description of embryogenesis and foetal organogenesis and proper blending of ancient knowledge with modern knowledge could be done.

4. Jyotish Science is complimentary to the Ayurvedic medical science and the extra description mentioned in Jyotish science related monthly foetal development should be incorporated in Ayurvedic science.

\section{Abbreviations :}

S.Sha. - Sushrut Sharirsthana, B.Ja. Brihat Jatakam, L.Ja. - Laghu Jatakam

\section{References:}

1. 'Sushrut Samhita' of acharya Sushruta edited and translated in hindi by Atridev, published by Motilal Banarasidas, 41, UA Bunglow Road, Jawahar nagar , Delhi-110007

2. 'Sushrut Samhita' of acharya Sushruta with Nibandhsangrah Commentary of acharya Dalhana, edited by Vd. Yadavji Trikamji, published by Chaukhamba Surbharati, Gopal Mandir Lane, Varanasi -221001

3. 'Ashtang Hrudayam' of acharya Vagbhata with Sarvansundari tika 
of acharya Arundutta, edited by Vd. Harishastri Paradkar, published by Chaukhamba Krushnadas Akadami, Gopal Mandir Lane, Varanasi -221001

4. 'Brihat Jatakam' of acharya Varaha Mihir, edited and translated in hindi by Pt. Kedarnath Joshi, reprint 2005, published by Motilal Banarasidas, 41, UA Bunglow Road, Jawahar nagar , Delhi110007

5. 'Laghu Jatakam' of acharya Varaha Mihir, edited by Brhmanand Tripathi and translated in hindi by Dr. Kamalakant
Pandeya , published by Chaukhamba Surbharati, Gopal Mandir Lane, Varanasi -221001

6. 'Human Anatomy' by Dr. B.D. Chaurasiya, $4^{\text {th }}$ edition ,published by CBS Publishers 4596/1, 11, Daryaganj, New Delhi - 110002

7. 'Text Book of Obstretics' by D.C. Dutta, $3^{\text {rd }}$ edition, reprint 1994, published by new central book Agency Pvt. Ltd., 8/1 Chintomoni Das Lane, Calcutta-700 009.

8. O Rahilly $\mathrm{R}$ and Muller $\mathrm{F}$. Developmental stages in human embryo. Contrib. Embryol., Caernegie Inst. Wash. 637 (1987)

\section{Cite article:}

Critical Comparative Study of Month wise Intrauterine Foetal Development As Per Ayurvedic And Jyotish Science W.S.R.To Modern Embryogenesis Subhash D. Waghe, Shrikant Darokar, Y.V. Rajyalakshmi Rao

Ayurlog: National Journal of Research in Ayurved Science- 2019; (7)(1): 1-10 